\title{
Free radical scavenging and a-glucosidase inhibitory effects of a roots extract of Aruncus dioicus var. kamtschaticus
}

\author{
Gyeong Han Jeong, Tae Hoon Kim* \\ Department of Food Science and Biotechnology, Daegu University, Gyeongsan 38453, Korea
}

\section{재배 삼나물 뿌리 추출물의 자유 라디칼소거 및 a-glucosidase 저해활성}

\author{
정경한 - 김태훈* \\ 대구대학교 식품공학과
}

\begin{abstract}
As part of our continuing search for bioactive natural products, the antioxidant and $\alpha$-glucosidase inhibitory activities of an $80 \%$ methanolic extract and organic solvent soluble-portions of Aruncus dioicus var. kamtschaticus roots were investigated by using a bioassay system. The antioxidant activity of $A$. dioicus var. kamtschaticus roots extract and organic solvent soluble-portions were assessed by examining with 1,1-diphenyl-2-picrylhydrazyl (DPPH) and 2,2'-azino-bis (3-ethylbenzothiazoline-6-sulphonic acid) $\left(\mathrm{ABTS}^{+}\right)$radical scavenging. In addition, anti-diabetic effects of the $A$. dioicus var. kamtschaticus root extract and organic solvent soluble-portions were tested via $\alpha$-glucosidase inhibition assay. The total phenolic contents of the products were determined by applying UV-VIS spectrophotometry. All tested samples showed dose-dependent radical scavenging and $\alpha$-glucosidase inhibitory properties. In particular, the a-glucosidase inhibitory and radical scavenging effects of the ethyl-acetate (EtOAc)-soluble portion from the roots of $A$. dioicus var. kamtschaticus were greater than those from other solvent-soluble portions. These results indicate that $\boldsymbol{A}$. dioicus var. kamtschaticus could be considered a new effective source of natural antioxidants and anti-diabetic materials. More systematic research of the constituents of the roots of this $A$. dioicus variety will be conducted to further develop its antioxidative and anti-diabetic properties.
\end{abstract}

Key words : Aruncus dioicus var. kamtschaticus, DPPH, ABTS ${ }^{+}, \alpha$-glucosidase inhibition

\section{서 론}

과도한 산화적 스트레스에 노출로 인한 현대인들은 각종 퇴행성 질환 및 습관성 질병에 건강과 일상생활을 위협 받고 있다. 과도하게 생성된 superoxide $\left(\mathrm{O}^{2}\right)$, nitric oxide (NO), nitrogen dioxide $\left(\mathrm{NO}_{2}\right)$, hydroxyl $(\mathrm{OH})$, peroxynitrite $\left(\mathrm{NO}_{3}\right)^{-}$등과 같은 활성산소종(reactive oxygen species, $\mathrm{ROS}$ ) 은 세포구성성분인 지질, 단백질, 당, DNA 등에 비 선택적, 비가역적 파괴를 촉진하게 된다 $(1,2)$. 이러한 산화 적 스트

*Corresponding author. E-mail : skyey7@daegu.ac.kr Phone : 82-53-850-6533, Fax : 82-53-850-6539

Received 6 September 2016; Revised 17 October 2016; Accepted 19 October 2016.

Copyright (c) The Korean Society of Food Preservation. All rights reserved.
레스는 노화를 촉진시키고 암, 뇌질환, 심혈관계 질환, 피부 질환 등의 각종 질병의 원인이 된다 $(3,4)$. 생체내의 ROS나 자유라디칼을 제거하여 노화방지, 성인병 예방 등의 기능 을 하는 성분을 항산화 물질이라고 하며, butylated hydroxy anisol(BHA), butylated hydroxy toluene(BHT) 등의 합성 항 산화제가 개발되어 사용되었으나 $(5,6)$, 이들 합성항산화제 는 암, 지질대사 불균형 등의 부작용에 의하여 사용이 제한 되고 있는 실정이다(7).

현대인들은 생활수준의 향상으로 인한 식습관의 변화로 대사성 질환 중의 하나인 당뇨병이 증가하고 있으며, 향후 전 세계 당뇨인구의 급격한 증가와 발병연령도 점차 낮아져 더 많은 인구가 당뇨병으로 인해 고통 받을 것으로 예측된 다(8). 당뇨병 중, 제 1 형은 췌장 베타세포의 병변에 따른 인슐린 결핍으로 인한 인슐린 의존성 당노, 제 2형은 인슐린 저항성으로 인한 인슐린 비의존성 당뇨로 정의된다 $(9,10)$ 
또한 산화적 스트레스는 췌장 베타세포의 손상과 인슐린 분비감소를 유발하여 항산화 성분은 당뇨병과 밀접하게 관련되어 있는 것이 알려져 있다(11). 한편, a-glucosidase는 소장점막에 존재하는 당분해 효소로서 이를 저해하면 탄수 화물의 소화를 방해하여 소장에서의 흡수가 지연되므로 식후 급격한 혈당상승을 막아준다(12). 천연물로부터 a -glucosidase 저해제의 분리 및 동정에 관한 다수의 연구가 수행되었으며(13), 특히 뽕나무의 플라보노이드인 mortatarins $\mathrm{D}$ 는 a-glucosidase의 우수한 저해제로 주목을 받고 있다 (14). 시판되는 a-glucosidase 저해제로는 acarbose 및 voglibose 가 있으나 이들을 장기 복용할 경우 각종 부작용 $(15,16)$ 으로 인하여 보다 안전하며 효능이 우수한 천연 기능성 소재의 탐색이 필요한 실정이다.

삼나물(Aruncus dioicus var. kamtschaticus)은 장미과 (Rosaceae)의 다년초로서 어린순은 식용가능하며 울릉도에 서 자생하는 산채로서 전국 각처의 고산지역에 자생하고 맛과 식감이 독특하여 고급 산채로 생산량이 확대되고 있다 (17). 삼나물의 지상부는 항산화(18), 항암(18), 항균(19), 항염증(20) 및 항 혈전(21) 등의 효능을 나타내며, 소수의 monoterpene류 및 flavoniod류(18) 등의 성분이 보고되어져 있다. 본 연구에서는 삼나물 뿌리의 $80 \%$ 메탄올 추출물 및 각 분획물에 대하여 항산화 및 항 당뇨 활성 평가를 위하여 $\mathrm{DPPH}, \mathrm{ABTS}^{+}$라디칼 소거능 및 $a$-glucosidase 저해 활성을 평가 하여 우수한 활성을 확인하였으므로 이들 결과 를 보고하고자 한다.

\section{재료 및 방법}

\section{재 료}

본 실험에 시료로 사용한 삼나물 뿌리(Aruncus dioicus var. kamtschaticus)는 충남 청양군 운곡면에서 재배되어 2016년도 3월에 채취한 신선한 삼나물 뿌리를 사용하였다. 표본시료는 대구대학교의 식품공학과 천연물화학 실험실 에 보관하고 있다. 본 실험에서 사용된 gallic acid, 2,2'azinobis-3-ethylbenzothiazoline-6-sulfonic acid(ABTS ${ }^{+}$), 1,1diphenyl-2-picrylhydrazyl(DPPH), Saccharomyces cerevisiae 유래의 a-glucosidase, (+)-catechin 및 acarbose은 SigmaAldrich chemical Co.(St. Louis, MO, USA) 구입하여 사용하 였고, 그 외에 사용된 용매 및 시약은 모두 일급 이상의 등급을 사용하였다.

\section{추출물의 제조 및 분획}

신선한 삼나물 뿌리 $1.6 \mathrm{~kg}$ 을 $80 \%$ 메탄올로 침지 추출을 3 회 반복하여 여과 한 후 농축하였다. 얻어진 삼나물 뿌리 $80 \%$ 메탄올 추출물 $(41.6 \mathrm{~g})$ 을 물에 현탁하여 저극성 용매인 n-hexane으로 먼저 추출한 후 수층을 다시 ethyl acetate
(EtOAc)와 $n$-butyl alcohol $(n-\mathrm{BuOH})$ 을 이용하여 각각 순차 적으로 5 회 분획하여 추출하였다. 각 용매추출 분획을 감압 농축하여 건조 시킨 후 각각 $n$-hexane 가용분획 $(0.9 \mathrm{~g})$, $\mathrm{EtOAc}$ 가용분획 $(41.6 \mathrm{~g}), n-\mathrm{BuOH}$ 가용분획 $(32.7 \mathrm{~g})$ 및 $\mathrm{H}_{2} \mathrm{O}$ 가용분획 $(54.5 \mathrm{~g})$ 을 각각 얻었으며 각 분획물을 대상으로 라디칼 소거능 및 a-glucosidase 저해능 평가를 수행하였다.

\section{총 페놀성 화합물 함량 측정}

총 페놀성 화합물의 함량은 Folin-Denis 방법(22)에 따라 측정하였으며, 추출물 혹은 분획물을 $1.0 \mathrm{mg} / \mathrm{mL}$ 농도로 조제한 후, 시료 $50 \mu \mathrm{L}$ 와 Folin-Denis 시액 $50 \mu \mathrm{L}, 0.7 \mathrm{M}$ 탄산나트륨 포화용액 $50 \mu \mathrm{L}$ 를 차례로 넣은 다음 이것을 잘 혼합하여 실온에서 60 분 방치한 후 UV/VIS 분광광도계 로 $750 \mathrm{~nm}$ 에서 흡광도를 측정하였으며, 표준물질은 gallic $\mathrm{acid}$ 를 이용하여 표준곡선을 작성하여 양을 환산하였다.

\section{$\mathrm{DPPH}$ 라디칼 소거능 측정}

삼나물 뿌리의 $80 \%$ 메탄올 추출물 및 분획물의 전자공여 능은 Blois 방법(23)에 따라 측정하였다. 각 시료용액에 120 $\mu \mathrm{L}$ 에 $0.45 \mathrm{mM}$ 의 DPPH 용액 $60 \mu \mathrm{L}$ 을 넣고 교반한 후 15 분 간 방치한 다음 $517 \mathrm{~nm}$ 에서 흡광도를 측정하였다. 전자공 여능은 시료용액의 첨가군과 무첨가군의 흡광도 차이를 백분율로 나타내었다.

\section{$\mathrm{ABTS}^{+}$라디칼 소거능 측정}

삼나물 뿌리의 $80 \%$ 메탄올 추출물 및 분획물에 대하여 $\mathrm{ABTS}^{+}$radical 소거능을 $\operatorname{Re}(24)$ 의 방법을 변형하여 다음과 같이 측정하였다. $7 \mathrm{mM} \mathrm{ABTS}{ }^{+}$와 $2.4 \mathrm{mM} \mathrm{K}_{2} \mathrm{O}_{8} \mathrm{~S}_{2}$ 동량을 혼합 후 실온, 암소에서 12시간 방치하여 라디칼의 생성을 유도한 후 $\mathrm{ABTS}^{+}$라디칼 용액을 희석하여 $734 \mathrm{~nm}$ 에서 흡광도 값이 0.7 0.8 정도가 되도록 희석한 후 사용하였다. 희석한 $\mathrm{ABTS}^{+}$라디칼 용액 $100 \mu \mathrm{L}$ 와 생약 추출액 $100 \mu \mathrm{L}$ 을 혼합하여 실온에서 7 분간 반응시킨 후 $734 \mathrm{~nm}$ 에서 흡광도 를 측정하였다. 이때 positive control로는 (+)-catechin을 사 용하였으며 결과는 시료를 처리하지 않은 군에 대한 백분율 로 나타내었다.

\section{$\mathrm{a}-$ Glucosidase 저해활성 측정}

a-Glucosidase 저해능은 $\operatorname{Eom}(25)$ 등이 행한 방법을 변형 하여 효소-기질반응을 이용한 분광학적 방법으로 측정하였 다. 즉, $1 \mathrm{U} / \mathrm{mL}$ a-glucosidase $90 \mu \mathrm{L}$ 에 시료 혹은 $0.1 \mathrm{M}$ sodium phosphate buffer(pH 6.8) $10 \mu \mathrm{L}$ 를 첨가하여 혼합한 후 $37^{\circ} \mathrm{C}$ 에서 15 분 동안 incubation 하였다. 반응 후 기질인 $1 \mathrm{mM} p$-NPG $100 \mu \mathrm{L}$ 를 첨가한 후 5분간 반응시키고 405 $\mathrm{nm}$ 에서 ELISA reader를 이용하여 흡광도를 측정함으로써 기질로부터 유리되어 나오는 p-nitrophenol을 측정하였다. 양성 대조군으로는 a-glucosidase 저해제로 알려진 acarbose 
를 사용하였으며 a-glucosidase 저해활성은 시료용액의 첨 가군과 무첨가군의 흡광도 감소율로 나타내었다.

\section{결과 및 고찰}

\section{총 페놀성 화합물 함량}

삼나물 뿌리 추출물 및 각 분획물의 총 페놀성 화합물의 함량을 Table 1에서와 같이 나타내었다. 먼저 EtOAc 분획물 은 $1 \mathrm{~g}$ 당 $90.1 \pm 1.6 \mathrm{mg}$ 의 페놀성 화합물을 함유하는 것으로 나타났으며, 삼나물 뿌리 $80 \%$ 메탄올 추출물은 $1 \mathrm{~g}$ 당 $37.6 \pm 3.1 \mathrm{mg}, n-\mathrm{BuOH}$ 분획물이 $1 \mathrm{~g}$ 당 $14.9 \pm 2.2 \mathrm{mg}, \mathrm{H}_{2} \mathrm{O}$ 층 에서는 $1 \mathrm{~g}$ 당 $7.1 \pm 1.8 \mathrm{mg}$ 의 페놀성 화합물의 함량이 확인되 었다. 또한 $n$-hexane 분획물이 $5.7 \pm 2.5 \mathrm{mg}$ 의 상대적으로 낮은 총페놀 함량을 나타내는 것으로 확인되었다.

Table 1. Total phenolic contents of the methanolic extract and organic solvent fractions of $\boldsymbol{A}$ dioicus var. kamtschaticus roots

\begin{tabular}{lc}
\hline \multicolumn{1}{c}{ Samples } & Phenolic contents $(\mathrm{mg} / \mathrm{g})^{1)}$ \\
\hline $80 \% \mathrm{MeOH}$ extract & $37.6 \pm 3.1$ \\
$n$-Hexane layer & $5.7 \pm 2.5$ \\
EtOAc layer & $90.1 \pm 1.6$ \\
$n-\mathrm{BuOH}$ layer & $14.9 \pm 2.2$ \\
$\mathrm{H}_{2} \mathrm{O}$ layer & $7.1 \pm 1.8$ \\
\hline
\end{tabular}

${ }^{1)}$ Data represent the mean \pm SD three replications. Inhibitory effects are expressed as the mean $\pm \mathrm{SD}$ of triplicate experiments.

\section{$\mathrm{DPPH}$ 라디칼 소거능 측정}

Table 2에서 나타낸 것처럼 삼나물 뿌리 $80 \%$ 메탄올 추출 물 및 각 유기용매 분획에 대해서 $\mathrm{DPPH}$ 라디칼 소거능을 측정한 결과, 삼나물 뿌리 $80 \%$ 메탄올 추출물 $\mathrm{IC}_{50}$ 값은 $161.9 \pm 4.4 \mu \mathrm{g} / \mathrm{mL}$ 라디칼 소거능을 나타내었으며, 특히 $\mathrm{EtOAc}$ 분획물이 $\mathrm{IC}_{50}$ 값이 $32.3 \pm 2.3 \mu \mathrm{g} / \mathrm{mL}$ 의 가장 우수한 라디칼 소거능을 나타내었고, 이 결과는 positive control로
사용된 (+)-catechin의 $\mathrm{IC}_{50}$ 값인 $73.0 \pm 3.4 \mu \mathrm{g} / \mathrm{mL}$ 보다 우수한 활성을 나타냄을 확인하였다. $n-\mathrm{BuOH}$ 분획물 또한 $\mathrm{IC}_{50}$ 값 이 $271.2 \pm 3.9 \mu \mathrm{g} / \mathrm{mL}$ 의 라디칼 소거능을 나타내었으며, $\mathrm{H}_{2} \mathrm{O}$ 층과 n-hexane 분획물에서는 $\mathrm{IC}_{50}$ 값이 $500 \mu \mathrm{g} / \mathrm{mL}$ 이상으로 상대적으로 낮은 라디칼 소거능을 나타내었다. 이상의 결 과는 삼나물 뿌리 추출물의 DPPH 라디칼 소거능은 Table 1 및 2에서 나타낸 것과 같이 EtOAc 분획층에서 페놀성 화합물의 함량이 상대적으로 높은 것을 확인할 수 있었으 며, DPPH 라디칼 소거능과 총 페놀 함량 사이에는 밀접한 상관관계가 있다는 보고(26)와도 일치하는 결과였다.

\section{$\mathrm{ABTS}^{+}$라디칼 소거능 측정}

Table 3에서 나타낸 것처럼 삼나물 뿌리 $80 \%$ 메탄올 추출 물 $\mathrm{IC}_{50}$ 값이 $31.9 \pm 1.2 \mu \mathrm{g} / \mathrm{mL}$ 의 $\mathrm{ABTS}^{+}$라디칼 소거능을 나 타냄을 확인하였으며, 각 분획물중에서도 $\mathrm{EtOAc}$ 분획의 $\mathrm{IC}_{50}$ 값이 $18.9 \pm 2.1 \mathrm{\mu g} / \mathrm{mL}$ 의 가장 우수한 라디칼 소거능을 나타내었으며, 이는 positive control인 (+)-catechin의 $\mathrm{IC}_{50}$ 값 인 $34.9 \pm 2.1 \mu \mathrm{g} / \mathrm{mL}$ 의 소거 활성에 상당하는 효능임을 확인 하였다. 또한 $n \mathrm{BuOH}$ 분획층은 $\mathrm{IC}_{50}$ 값이 $51.0 \pm 2.9 \mathrm{\mu g} / \mathrm{mL}$ 라디칼 소거능을 나타내었다. EtOAc 분획층의 $100 \mu \mathrm{g} / \mathrm{mL}$ 에서 $85.1 \%, 50 \mu \mathrm{g} / \mathrm{mL}$ 의 농도에서 $82.8 \%, 25 \mu \mathrm{g} / \mathrm{mL}$ 의 농도 에서 $60.9 \%$ 의 라디칼 소거능을 나타내었다. 한편, $\mathrm{H}_{2} \mathrm{O}$ 분획 층과 $n$-hexane 분획에서는 $\mathrm{IC}_{50}$ 값이 $200 \mu \mathrm{g} / \mathrm{mL}$ 이상으로 상대적으로 낮은 라디칼 소거 활성을 나타내었다. Table 1 에서 나타낸 것처럼 총 페놀 함량이 상대적으로 높은 $\mathrm{EtOAc}$ 분획층에서 $\mathrm{ABTS}^{+}$라디칼 소거 활성이 우수한 화합 물의 존재가 시사되었다. 최근의 연구에서 삼나물 지상부 에 라디칼 소거활성을 나타내는 flavonoid류(18)의 보고는 있으나, 삼나물 뿌리의 라디칼 소거 활성 및 관련 성분에 대한 보고는 이번이 처음이며, 삼나물 뿌리 추출물의 $\mathrm{EtOAc}$ 분획물에 존재하는 활성 물질의 동정이 필요하다고 사료된다.

Table 2. DPPH radical scavenging activity of the $80 \%$ methanolic extract of $A$ dioicus var. kamtschaticus roots and its $n$-hexane, EtOAc-, $n$-BuOH-, and $\mathrm{H}_{2} \mathrm{O}$-soluble portions

\begin{tabular}{lcccccc}
\hline \multirow{2}{*}{ Sample $(\mu \mathrm{g} / \mathrm{mL})$} & \multicolumn{5}{c}{ Inhibition $(\%)$} & \multirow{2}{*}{ IC $_{50}(\mu \mathrm{g} / \mathrm{mL})^{1)}$} \\
\cline { 2 - 6 } & 500 & 250 & 125 & 62.5 & 31.3 & $161.9 \pm 4.4$ \\
80\% MeOH ext. & $89.8 \pm 2.3$ & $66.8 \pm 2.0$ & $39.7 \pm 1.7$ & $17.4 \pm 0.5$ & $8.9 \pm 0.3$ & $>500$ \\
$n$-Hexane layer & $20.4 \pm 0.8$ & $11.3 \pm 0.6$ & $10.6 \pm 0.5$ & $6.6 \pm 0.3$ & $3.3 \pm 0.1$ & $32.3 \pm 2.3$ \\
EtOAc layer & $94.9 \pm 3.1$ & $94.0 \pm 1.6$ & $89.7 \pm 1.4$ & $71.8 \pm 1.4$ & $48.9 \pm 0.9$ & $271.2 \pm 3.9$ \\
$n$-BuOH layer & $71.4 \pm 2.9$ & $45.9 \pm 1.8$ & $26.5 \pm 1.5$ & $13.3 \pm 1.1$ & $8.4 \pm 0.7$ & $>500$ \\
$\mathrm{H}_{2}$ O layer & $38.9 \pm 2.1$ & $22.1 \pm 1.4$ & $12.7 \pm 1.6$ & $7.3 \pm 1.1$ & $6.9 \pm 0.7$ & $73.0 \pm 3.4$ \\
$(+)$-Catechin & $99.9 \pm 1.6$ & $99.9 \pm 1.5$ & $96.7 \pm 1.1$ & $29.2 \pm 0.5$ & $7.3 \pm 0.6$ & \\
\hline
\end{tabular}

\footnotetext{
${ }^{1)}$ All samples were examined in triplicate experiments. Inhibitory effects are expressed as the mean $\pm \mathrm{SD}$ of triplicate experiments.
}

${ }^{2)}(+)$-Catechin was used as a positive control. 
Table 3. $\mathrm{ABTS}^{+}$radical scavenging activity of the $80 \%$ methanolic extract of $A$ dioicus var. kamtschaticus roots and its $n$-hexane-, EtOAc-, $n$-BuOH-, and $\mathrm{H}_{2} \mathrm{O}$-soluble portions

\begin{tabular}{|c|c|c|c|c|c|c|}
\hline \multirow{2}{*}{ Sample $(\mu \mathrm{g} / \mathrm{mL})$} & \multicolumn{5}{|c|}{ Inhibition (\%) } & \multirow{2}{*}{$\mathrm{IC}_{50}(\mu \mathrm{g} / \mathrm{mL})^{1)}$} \\
\hline & 200 & 100 & 50 & 25 & 12.5 & \\
\hline $80 \% \mathrm{MeOH}$ extract & $94.2 \pm 2.7$ & $88.6 \pm 2.2$ & $42.6 \pm 2.0$ & $21.5 \pm 1.1$ & $12.8 \pm 0.7$ & $31.9 \pm 1.2$ \\
\hline$n$-Hexane layer & $10.3 \pm 0.7$ & $8.2 \pm 0.5$ & $5.3 \pm 0.3$ & $3.9 \pm 0.2$ & $1.8 \pm 0.2$ & $>200$ \\
\hline EtOAc layer & $91.0 \pm 2.8$ & $85.1 \pm 2.4$ & $82.8 \pm 2.1$ & $60.9 \pm 1.8$ & $35.4 \pm 1.5$ & $18.9 \pm 2.1$ \\
\hline$n-\mathrm{BuOH}$ layer & $68.6 \pm 2.3$ & $40.4 \pm 2.1$ & $21.0 \pm 0.7$ & $8.4 \pm 0.5$ & $2.7 \pm 0.2$ & $51.0 \pm 2.9$ \\
\hline $\mathrm{H}_{2} \mathrm{O}$ layer & $1.7 \pm 0.1$ & $1.4 \pm 0.2$ & $1.1 \pm 0.2$ & $0.5 \pm 0.1$ & $0.3 \pm 0.1$ & $>200$ \\
\hline (+)-Catechinn ${ }^{2}$ & $99.9 \pm 2.3$ & $99.9 \pm 2.0$ & $71.8 \pm 1.8$ & $28.4 \pm 1.1$ & $8.9 \pm 0.8$ & $34.9 \pm 2.1$ \\
\hline
\end{tabular}

${ }^{11}$ All samples were examined in triplicate experiments. Inhibitory effects are expressed as the mean \pm SD of triplicate experiments.

${ }^{2)}(+)$-Catechin was used as a positive control.

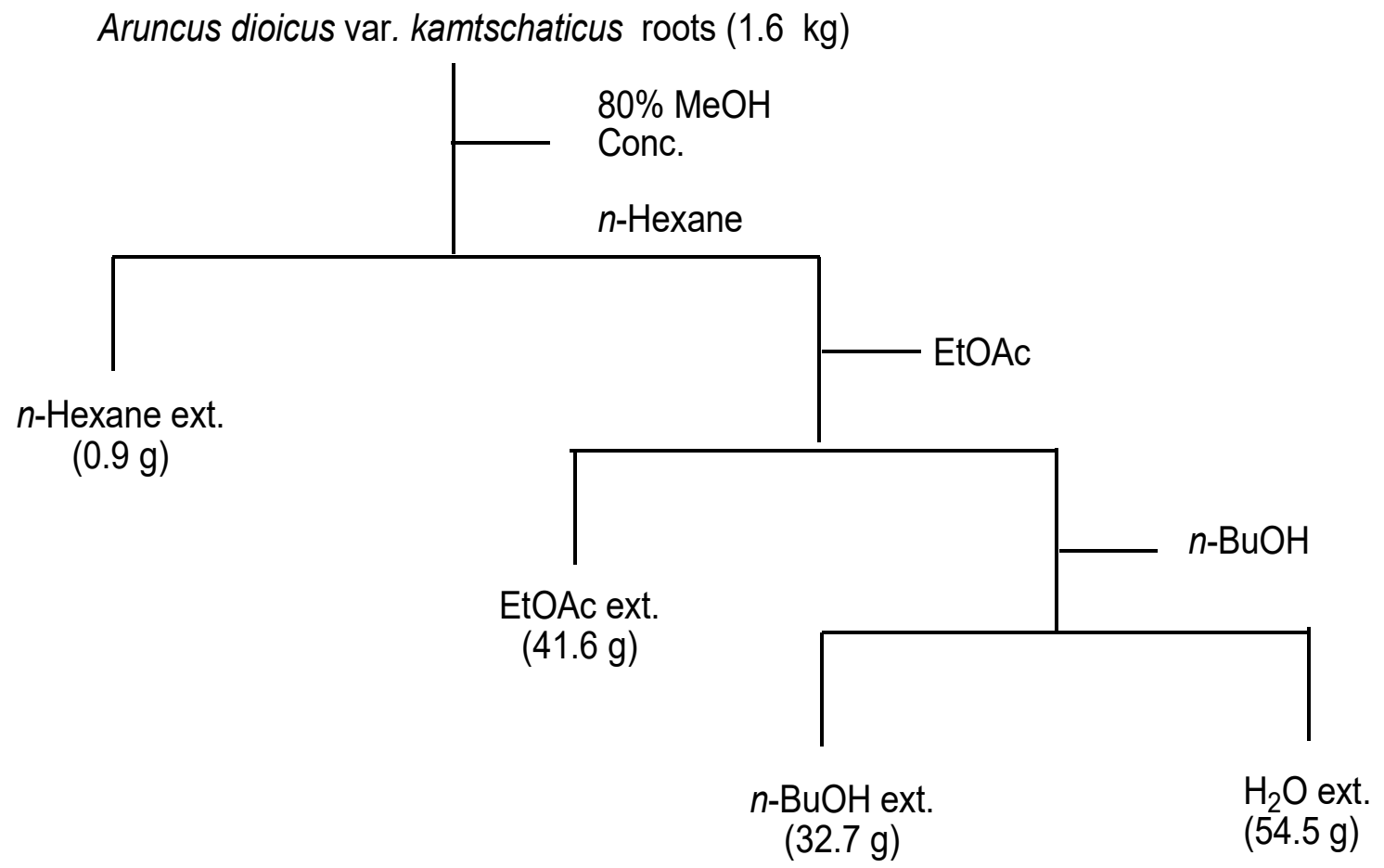

Fig. 1. Liquid-liquid partition of Aruncus dioicus var. kamtschaticus roots.

Table 4. Inhibitory effects of the $80 \%$ methanolic extract of $A$ dioicus var. kamtschaticus roots and its $n$-hexane-, EtOAc-, $n$-BuOH-, and $\mathrm{H}_{2} \mathrm{O}$-soluble portions against a-glucosidase

\begin{tabular}{|c|c|c|c|c|c|c|}
\hline \multirow{2}{*}{ Sample $(\mu \mathrm{g} / \mathrm{mL})$} & \multicolumn{5}{|c|}{ Inhibition (\%) } & \multirow{2}{*}{$\mathrm{IC}_{50}(\mu \mathrm{g} / \mathrm{mL})^{1}$} \\
\hline & 500 & 250 & 125 & 62.5 & 31.3 & \\
\hline $80 \% \mathrm{MeOH}$ extract & $80.0 \pm 2.3$ & $58.1 \pm 1.8$ & $37.3 \pm 1.7$ & $13.0 \pm 1.2$ & $4.9 \pm 0.7$ & $198.0 \pm 8.8$ \\
\hline$n$-Hexane layer & $9.9 \pm 1.2$ & $7.3 \pm 1.0$ & $3.2 \pm 0.5$ & $0.5 \pm 0.1$ & $0.2 \pm 0.1$ & $>500$ \\
\hline EtOAc layer & $99.8 \pm 2.0$ & $85.6 \pm 2.3$ & $66.6 \pm 1.9$ & $49.9 \pm 1.7$ & $38.0 \pm 0.3$ & $57.8 \pm 7.8$ \\
\hline$n-\mathrm{BuOH}$ layer & $64.5 \pm 1.8$ & $51.1 \pm 1.1$ & $35.5 \pm 1.0$ & $23.7 \pm 0.5$ & $11.5 \pm 0.2$ & $251.7 \pm 10.1$ \\
\hline $\mathrm{H}_{2} \mathrm{O}$ layer & $38.9 \pm 1.6$ & $25.1 \pm 0.8$ & $16.0 \pm 0.5$ & $7.3 \pm 0.5$ & $5.3 \pm 0.1$ & $>500$ \\
\hline Acarbose $^{2)}$ & $50.6 \pm 2.5$ & $43.1 \pm 0.9$ & $37.8 \pm 2.1$ & $5.7 \pm 1.1$ & $3.5 \pm 0.9$ & $501.1 \pm 17.5$ \\
\hline
\end{tabular}

\footnotetext{
${ }^{11}$ All samples were examined in triplicate experiments. Inhibitory effects are expressed as the mean $\pm \mathrm{SD}$ of triplicate experiments.
}

${ }^{2)}$ Acarbose was used as a positive control. 
a-Glucosidase 저해 활성 측정

시판되는 대표적인 당뇨 치료제인 acarbose와 voglibose 는 장기간 복용 시 구토 및 설사를 비롯한 복부팽만감 등의 부작용으로 인하여 보다 안전한 천연물 유래의 소재 개발에 관한 연구가 활발하게 진행되어지고 있다(27). 본 연구의 결과, Table 4에서 나타낸 것처럼 삼나물 뿌리 $80 \%$ 메탄올 추출물의 $\mathrm{IC}_{50}$ 값이 $198.0 \pm 8.8 \mu \mathrm{g} / \mathrm{mL}$ 의 활성을 나타내었고, 총 페놀 함량이 가장 높은 $\mathrm{EtOAc}$ 가용부의 $\mathrm{IC}_{50}$ 값이 $57.8 \pm 7.8 \mu \mathrm{g} / \mathrm{mL}$ 으로 가장 우수한 활성은 나타내었으며, 다 음으로 $n-\mathrm{BuOH}$ 분획층의 $\mathrm{IC}_{50}$ 값은 $251.7 \pm 10.1 \mu \mathrm{g} / \mathrm{mL}$ 의 활 성을 나타났다. 이들 활성은 양성대조구인 acarbose의 $\mathrm{IC}_{50}$ 값인 $501.1 \pm 17.5 \mathrm{\mu g} / \mathrm{mL}$ 과 비교할 때 EtOAc 가용분획의 활 성은 우수한 효능임을 확인하였다. 최근의 연구 $(28,29)$ 에 의하면 단풍취(Ainsliaea acerifolia) 추출물의 EtOAc 가용 부의 $\mathrm{IC}_{50}$ 값은 $103.4 \mathrm{\mu g} / \mathrm{mL}$, 오디(Morus alba) 와인의 polystyren 수지 칼럼 충진제를 활용한 $80 \%$ 에탄올 용리액 의 $\mathrm{IC}_{50}$ 값은 $70.2 \mu \mathrm{g} / \mathrm{mL}$ 의 a-glucosidase의 저해 활성을 나타내었다. 이들 활성과 비교하면 삼나물 뿌리의 EtOAc 가용부의 우수한 활성을 확인하였으며, 향후 활성물질의 동정을 통한 활성기작 연구가 필요하다고 사료된다.

\section{요 약}

삼나물 뿌리를 $80 \%$ 메탄올로 침지 추출하여 얻어진 추출 물에 대해 $n$-hexane, EtOAc 및 $n-\mathrm{BuOH}$ 의 유기용매를 활용 하여 순차 분획을 실시하였고, 얻어진 결과물에 대하여 $\mathrm{DPPH}, \mathrm{ABTS}^{+}$라디칼 소거능 및 a-glucosidase 저해활성을 평가하였다. $\mathrm{DPPH}$ 라디칼 소거능은 총 페놀성 화합물의 함량이 상대적으로 높은 $\mathrm{EtOAc}$ 층에서 $\mathrm{IC}_{50}$ 값이 $32.3 \pm 2.3$ $\mu \mathrm{g} / \mathrm{mL}$ 으로 가장 우수한 DPPH 라디칼 소거능을 확인하였 고, 삼나물 뿌리 의 EtOAc 가용부에 다량 존재하는 페놀성 화합물과 라디칼 소거능과의 연관성을 시사하였다. 또한 $\mathrm{ABTS}^{+}$라디칼 소거능은 $\mathrm{EtOAc}$ 층의 $\mathrm{IC}_{50}$ 값이 $18.9 \pm 2.1 \mu$ $\mathrm{g} / \mathrm{mL}$ 의 우수한 라디칼 소거활성이 확인 하였고, 우수한 라디칼 소거 활성물질의 존재가 시사되었다. 또한, $a$ -glucosidase 저해활성을 평가한 결과, 우수한 라디칼 소거 능을 나타낸 $\mathrm{EtOAc}$ 층의 $\mathrm{IC}_{50}$ 은 $57.8 \pm 7.8 \mu \mathrm{g} / \mathrm{mL}$ 의 저해활성 을 나타내었으며, 이는 positive control인 acarbose의 $\mathrm{IC}_{50}$ 값 인 $501.1 \pm 17.5 \mu \mathrm{g} / \mathrm{mL}$ 과 비교하여 우수한 활성이었으며, 추 출물 상태의 시료를 단일물질로 정제할 경우 더욱 강한 효능의 화합물이 존재할 가능성을 시사하였다. 향후 이들 활성물질 동정을 통한 활성 기작에 대한 연구가 필요하며 본 연구결과는 보다 우수한 라디칼 소거능 및 a-glucosidase 저해능을 가지는 새로운 기능성 소재 발굴을 위한 기초자료 로 활용 가능할 것으로 사료된다.

\section{References}

1. Videla LA, Fermandez V (1988) Biochemical aspects of cellular oxidative stress. Arch Biol Med Exp, 21, 85-92

2. Halliwell B, Aruoma OJ (1991) DNA damage by oxygen-derived species. FEBS Lett, 281, 9-19

3. Jennings PE, Barnett AH (1988) New approaches to the pathogenesis and treatment of diabetic microangiopathy. Diabeti Med, 5, 111-117

4. Shim JS, Kim SD, Kim TS, Kim KN (2005) Biological activities of flavonoid glycosides isolated from Angelica keiskei. Korean J Food Sci Technol, 37, 78-83

5. Farag RS, Badei AZMA, Hewedi GSA, Baroty EL (1984) Antioxidant activity of some spice essential oils on linoleic acid oxidation in aqueous media. J Am Oil Chem Soc, 66, 792-799

6. Frei B (1994) National antioxidants in human health and disease. Academic Press, San Diego, 44-55

7. Branen AL (1975) Toxicology and biochemistry of butylated hydroxy anisole and butylated hydroxy toluene. J Am Oil Chem Soc, 52, 59-62

8. Rubin RR, Peyrot M (1999) Quality of life and diabetes. Diabetes Metab Res Rev, 15, 205-218

9. Lee SH, Lee JK, Kim IH (2012) Trends and perspectives in the development of antidiabetic drugs for type 2 diabetes mellitus. Korean J Microbiol Biotechnol, 40, 180-185

10. Lee EB, Na GH, Ryu CR, Cho MR (2004) The review on the study of diabetes mellitus in oriental medicine journals. J Korean Orient Med, 25, 169-179

11. Schwarz K, Mertz W (1959) Chromium (III) and the glucose tolerance factor. Arch Biochem Biophys, 85, 292-295

12. Robertson RP, Harmon J, Tran PO, Poitout V (2004) $\beta$-Cell glucose toxicity, lipotoxicity and chronic oxidative stress in type 2 diabetes. Diabetes, 53, 5119-5124

13. Zhang A, Ye F, Lu J, Zhao S (2013) Screening a -glucosidase inhibitor from natural products by capillary electrophoresis with immobilized enzyme onto polymer monolith modified by gold nanoparticles. Food Chem, 141, 1854-1859

14. Zhang YL, Luo JG, Wan CX, Zhou ZB, Kong LY (2015) Four new flavonoids with a-glucosidase inhibitory activities from Morus alba var. tatarica. Chem Biodivers, 12, 1768-1776

15. Tsujimoto T, Shioyama E, Moriya K, Kawaratani H, Shirai Y, Toyohara M, Mitoro A, Yamao J, Fujii H, Fukui 
H (2008) Pneumatosis cystoides intestinalis following alpha-glucosidase inhibitor treatment: a case report and review of the literature. World J Gastroenterol, 14, 6087-6092

16. Kihara Y, Ogami Y, Tabaru A, Unoki H, Otsuki M (1997) Safe and effective treatment of diabetes mellitus associated with chronic liver diseases with an alpha-glucosidase inhibitor acarbose. J Gastroenterol, 32, 777-782

17. Kim DH, Moon YS, An BJ, Son JH (2012) Potent anti-aging activity of Aruncus dioicus, a native plant of Ulleung-do, South Korea, in CCD-986sk fibroblasts via suppression of matrix metalloproteinases. J Nat Med, 66, 631-636

18. Jeong SY, Kim YH, Min BS, Min BK, Woo MH (2011) Monoterpenoids from the aerial parts of Aruncus dioicus var. kamtschaticus and their antioxidant and cytotoxic activities. Bioorg Med Chem Lett, 21, 3252-3256

19. Kim MS (2011) Antioxidative and antimicrobial activities of Aruncus dioicus var. kamtschaticus Hara extracts. Korean Soc Food Sci Nutr, 40, 47-55

20. Zang Q, Kim HY (2014) DNA damage protection and anti-inflammatory activity of different solvent fractions from Aruncus dioicus var. kamtschaticus. Korean J Plant Res 27, 714-719

21. Kim MS, Son HY (2014) Anti-thrombosis activity of the aerial part of Aruncus dioicus var kamtschaticus. J Life Sci, 24, 515-521
22. Gao X, Bjor, L, Trajkovski V, Uggla M (2000) Evaluation of antioxidant activities of rosehip ethanol extracts in different test system. J Sci Food Agric, 80, 2021-2027

23. Blois MS (1958) Antioxidant activity determination by the use of a stable free radical. Nature, 181, 1199-1200

24. Re R, Pellegrini N, Proteggente A, Pannala A, Yang M, Rice-Evans C (1999) Antioxidant activity applying an improved ABTS radical cation decolorization assay. Free Radic Biol Med, 26, 1231-1237

25. Eom SH, Lee $\mathrm{SH}$, Yoon NY, Jung WK, Jeon YJ, Kim SK, Lee MS, Kim YM (2012) a-Glucosidase and a -amylase inhibitory activities of phlorotannins from Eisenia bicyclis. J Sci Food Agric, 92, 2084-2090

26. Wang SY, Chang HN, Lin KT, Lo CP, Yang NS, Shyur LF (2003) Antioxidant properties and phytochemical characteristics of extracts from Lactuca indica. J Agric Food Chem, 26, 1506-1512

27. Bischoff $H$ (1995) The mechanism of alpha-glucosidase inhibition in the management of diabetes. Clin Invest Med, 18, 303-311

28. Lee EW, Kim TW, Kim, HS, Park YM, Kim SH, Im MH, Kaak JH, Kim TH (2015) Antioxidant and a -glucosidase inhibitory effects of ethanolic extract of Ainsliaea acerifolia and organic solvent-soluble fractions. Korean J Food Preserv, 22, 275-280

29. Son WR, Choi SW (2013) Biological activity and analysis of a-glucosidase inhibitor from mulberry (Morus alba L.) wine. Korean J Food Preserv, 20, 877-885 